\title{
DE LAATSTE VRIJE INCAS?
}

In „Het Koloniaal Weekblad” van 15 Januari j.l. stond het volgende stuk:

„Georges Brousseau heeft met twee korjalen, elk bemand met zes man uit Cayenne, een reis ondernomen naar het brongebied van de Marowijne - juister: naar de Aloërivier, een linkerzijrivier van de Itanie - om avonturen en goud te zoeken, en vertelt daarvan wonderlijke dingen in „La Revue Mondiale” van 15 Juni 1924. In de "Wetenschappelijke Bladen" van November j.l. vinden wij een vertaling onder het hoofd: „De laatste vrije Incas”.

Het toeval voerde de reizigers naar het dorp Yamaïké, dat, volgens Brousseau, nog door geen vreemdeling was bezocht en dat bewoond is door den wilden stam der Coulais, die, evenals de Trio's, ieder verkeer met hun buren vermijden. (Van de Trio's blijkt dit niet uit de Goeje's ,Verslag van de Toemoekhoemak-expeditie").

De Goeje zegt op blz. 174 van de „Encyclopaedie van Nederlandsch West-Indiē dat de Ojarikoelé (de Coulais van Brousseau) allen vreemdelingen vijandig gezind zijn en dat zoowel de Ojana's als de Bonninegers meermalen strijd met hen gevoerd hebben.

Brousseau was gelukkiger. Uit den mond der ouden en van den „,hoogepriester" der Coulais en Trio's vernam hij de geheele waarheid omtrent hun oorsprong.

(Men zou hier willen vragen in welke taal hij zich met de Coulais onderhield).

Die geheele waarheid was de volgende: Hun voorouders leefden gelukkig in een groote stad van meer dan honderdduizend inwoners - (hebben deze Indianen begrip van zulke groote getallen?) - Tamboe Tocco, in de bergpassen van den Uru bamba, ten noorden van Cusco. Plotseling vernamen zij dat de Spanjaarden in hun land gekomen waren en overal schrik en dood verspreidden. Deze wilden goud hebben, steeds meer goud. Toen zij niets meer vonden, namen zij de foltering door het ijzer en het vuur te baat, onder het voorwendsel dat de Indianen hunne goden moesten verloochenen en die der bleekgezichten aannemen. 
Tamboe Tocco, diep in het woud gelegen, ontsnapte aan de nasporingen der Spanjaarden. Onderwijl was men op zijn hoede en gereed om in alle haast te vluchten, met medeneming van alle kostbare voorwerpen, in het bijzonder de fabelachtige schatten uit de tempels en uit het paleis met de Drie Vensters. Toen de laatste keizer onder de martelingen der Spaansche Inquisitie bezweken was zonder te hebben bekend gemaakt waar de schatten zich bevonden, werd tot den uittocht besloten. Honderd en twintig duizend menschen vluchtten in duizenden prauwen langs de Urayali. $\mathrm{Zij}$ werden aangevoerd door twee tamoesies, prinsen der keizerlijke familie: Tumac Humac en Mango Humac.

In 1917 ontdekte een Amerikaansch ontdekkingsreiziger de stad Tamboe-Tocco.

Francisco Orellana vervolgde de vluchtelingen en haalde hen in den middenloop van de Maragnon in. De Indianen hadden lange haren, geen baard of bijna geen, waaruit de legende van de Amazonen ontstond. Geen enkele vrouw had aan den strijd deelgenomen.

De vluchtelingen hadden zich neergezet aan de Maragnon, nabij den mond van een der zijrivieren uit het Noorden, waaraan zij den naam van hun land Peru of Paroe gaven, maar trokken later over de stroomversnellingen en watervallen tot aan den oorsprong van de Paroe in de bergen, die zij Tumac Humac noemden. Zij verspreidden zich vervolgens in de naburige landen, steeds naar het Noorden trekkend. Op deze wijze ontdekten zij het Parima-meer in het hart van een vulkanisch gebergte, de Parima-bergen der Engelsche kaarten.

....,Gelukkiger dan Walther Raleigh, - aldus Brousseau heb ik met twee eenvoudige prauwen de laatste vrije Inca's gevonden onder den naam Coulais en Trios, aan de grenzen der drie Boven-Guiana's"....

Wat denkt de Goeje van dit verhaal? Wahrheit oder Dichtung?"

Wij zonden het blad aan den heer C. H. de Goeje toe, die zoo vriendelijk was daarop het volgende bescheid te geven:

„De reis van Georges Brousseau schijnt geweest te zijn een prospectie-tocht naar goud. Het Ojana-dorp Jamaiké is indertijd door Henri Coudreau bezocht, en ook in 1903 door Franssen Herderschee, Versteeg en mij met stadsnegers en twee Boni-boschnegers. In dien tijd heette het, dat tusschen Lawa en Tapanahoni, diep in het binnenland vijandige Indianen van den stam der Ojarikoele's woonden. Wij bevonden echter de bronrivieren van de 
Gonini onbewoond, en de Gouvernements Mijnexploratie, die later de Oelemarie opvoer, vond evenmin Indianen. Het is echter nog mogelijk dat de Ojarikoele's wonen aan de verder in het Zuiden gelegen Loë (Aloë) kreek, welker monding wij voorbijvoeren. Het is vrijwel zeker dat enkele weken tevoren een Surinaamsch goudzoeker nabij de Oelemarie door een Indiaanschen pijl is gewond, en wij vonden daar ook verscheidene verlaten goudzoeker-kampen. Maar is de schutter een vreemde Indiaan geweest, of was er een kleine ruzie met Ojana's?

$\mathrm{Er}$ is geen reden om er aan te twijfelen dat de schrijver de Loëkreek heeft opgevaren, en het is wel mogelijk dat hij daar Indianen heeft ontmoet. De rest ziet er nogal onwaarschijnlijk uit.

Er bestaat geen geschrift over de taal der Ojarikoele's. Het is niet uitgesloten dat hunne taal (indien zij werkelijk nog als stam bestaan) verwant is aan het Ojana en het Trio. (B. noemt de Triọ's hunne verwanten), maar zelfs iemand die de bestaande geschriften over l.g. talen grondig bestudeerd heeft, zal daaraan niet genoeg hebben om een zoo lang en ingewikkeld verhaal zonder misverstand op te nemen. Uit het stuk blijkt echter ten duidelijkste dat B. onkundig is van de publicaties over die talen en ook niets weet van de vriendschappelijke aanrakingen van de Nederlandsche expedities met de Trio's. Het is niet waarschijnlijk dat er een tolk is geweest die de taal verstond van een stam die niet met anderen verkeert.

B. zegt dat Oyaricoulai in de Karaïbische taal zeggen wil: snelle rivier der Coulais. Indien een woord Oyari in het Karaïbisch „,snelle rivier" beduidt, dan zou een Karaïb niet zeggen Oyari-coulai, doch Coulai-oyari.

Aan het slot vertelt hij: „Arcabussa!” (van het Spaansche woord arcabusa, haakbus) zeiden zij met een afgrijselijken en geheimzinnigen haat bij het zien van mijn eenvoudig jachtgeweer."

Dat geeft echter geen aanwijzing dat deze Indianen destijds voor de Spanjaarden uit Peru zijn gevlucht, want het woord arkabussa is in gebruik bij alle Indianenstammen in Guyana en vermoedelijk overgenomen van de eerste Spanjaarden die de Antillen en Venezuela bezochten.

Het woord Tamboe Tocco lijkt sterk op het Trio-woord voor hoofdman of grijsaard: tamoetoepeu. De afleiding van den naam Tumac Humac is, al het hier gezegde in aanmerking nemende, niet dadelijk aan te nemen, en de afleiding van den naam Peru slechts als de schrijver eerst kennis neemt van de studie van Dr. 
Rivet over dezen naam ${ }^{1}$ ) en aantoont dat diens conclusies onjuist zijn.

B. geeft te kennen dat deze z.g. afstammelingen van de Inca's eene Karaïbische taal spreken. Maar de Indianen in Peru spraken geen Karaïbisch, daarentegen werden Karaïben in Guyana en op de Kleine Antillen aangetroffen door de Spanjaarden, lang vóór zij Peru bezochten.

Een geheel andere vraag: acht de Regeering het wenschelijk dat in een gedeelte van Suriname waar Indianen wonen en misschien zelfs wilde Indianen, en waar geen bestuursambtenaren en politie of troepen zijn, vreemde goudzoekers komen?"

1) Dr. Rivet, A propos de l'origine du mot „Pérou”. L'Anthropologie T. XXII-1911. p. $289-294$. 